\title{
PEMBIAYAAN NATURAL CERTAINTY CONTRACT (NCC) DAN PEMBIAYAAN NATURAL UNCERTAINTY CONTRACT (NUC) PADA PROFITABILITAS BANK UMUM SYARIAH
}

\author{
Atieq Amjadallah Alfie \\ Maftuchatul Khanifah \\ Fakultas Ekonomi Universitas Wahid Hasyim \\ (atiqalfie@unwahas.ac.id)
}

\begin{abstract}
Abstrak
Penelitian ini dilakukan dengan tujuan untuk menguji pengaruh Pembiayaan Natural Certainty Contract (NCC) dan Pembiayaan Natural Uncertainty Contract (NUC) Terhadap Profitabilitas (ROA). Sampel yang digunakan dalam penelitian ini berjumlah 24 dengan kriteria 6 Bank umum syariah yang sama, selama 4 tahun penelitian. Metode pengambilan sampel dengan menggunakan Purposive Sampling. Adapun metode analisis data yang digunakan adalah uji asumsi klasik, Analisis regresi linier berganda, dan uji t (uji parsial).

Hasil dari penelitian ini menunjukan bahwa dari jenis Pembiayaan Natural Certainty Contract (NCC) yaitu variabel pembiayaan Murabahah berpengaruh positif tidak signifikan terhadap profitabilitas (ROA), Pembiayaan Ijarah berpengaruh positif tidak signifikan terhadap profitabilitas (ROA), Pembiayaan Istishna berpengaruh positif tidak signifikan terhadap profitabilitas (ROA) dan jenis Pembiayaan Natural Uncertainty Contract (NUC) yaitu Pembiayaan Mudharabah tidak berpengaruh positif dan tidak signifikan terhadap profitabilitas (ROA), sedangkan pembiayaan Musyarakah berpengaruh positif tidak signifikan terhadap profitabilitas (ROA).
\end{abstract}

Kata Kunci : Profitabilitas (ROA), Murabahah, Ijarah, Istishna, Mudharabah, dan Musyarakah. 


\begin{abstract}
This research was conducted with the aim to examine the effect of Financing of Natural Certainty Contracts (NCC) and Financing of Natural Uncertainty Contracts (NUC) on Profitability (ROA). The sample used in this study amounted to 24 with criteria 6 of the same sharia commercial bank, for 4 years of research. Sampling method using Purposive Sampling. The data analysis method used is the classic assumption test, multiple linear regression analysis, and t test (partial test).

The results of this study show that from the type of Natural Certainty Contract (NCC) financing, namely Murabahah financing variable, it has a significant positive effect on profitability (ROA), Ijarah Financing has no significant positive effect on profitability (ROA), Istishna Financing has no significant positive effect on profitability ( ROA) and type of Financing Natural Uncertainty Contract (NUC), namely Mudharabah Financing does not have a positive and not significant effect on profitability (ROA), while Musyarakah financing has a positive and not significant effect on profitability (ROA).
\end{abstract}

Keywords: Profitability (ROA), Murabahah, Ijarah, Istishna, Mudharabah, and Musyarakah. 


\section{A. Pendahuluan}

Menurut UU Perbankan Syariah Indonesia No. 21 tahun 2008, disebutkan bahwa bank syariah adalah bank yang menjalankan kegiatan usahanya berdasarkan prinsip syariah yang terdiri atas Bank Umum Syariah (BUS) dan Bank Pembiayaan Rakyat Syariah (BPRS). BUS adalah bank syariah yang kegiatanya memberikan jasa dalam lalu lintas pembayaran. Dalam UU tersebut juga dikatakan bahwa bank konvensional yang hendak melaksanakan usaha syariah harus membentuk Unit Usaha Syariah (UUS) yang khusus beroperasi dengan sistem syariah. ${ }^{1}$

Bank tebagi menjadi dua yaitu bank syariah dan bank konvesional. Kedua jenis bank yang hampir sama, hanya berbeda dalam sistem bunga,sedangkan bank syariah menerapkan sistem bagi hasil. Produk bank yang menerapkan sistem bagi hasil adalah pada pembiayaan modal kerja dan investasi dalam bentuk pembiayaan mudharabahdan musyarakah.

Pembiayaan merupakan penyediaan uang atau tagihan berdasarkan persetujuan antara bank dan pihak lain yang wajib untuk mengembalikan uang atau tagihan setelah jangka waku tertentu dengan imbalan atau bagi hasil. Pembiayaan adalah penyediaan uang atau tagihan yang dapat dipersamakan dengan itu, secara luas pengertian tersebut dapat diartikan sebagi penyediaan uang atau tagihan yang dapat dipersamakan dengan itu, berdasarkkan persetujuan atau kesepakatan pinjam meminjam antara lembaga keuangan pihak lain yang mewajibkan pihak peminjam untuk melunasi utangnya setelah jangka waktu tertentu, dengan imbalan atau bagi hasil. Tingginya tingkat kepercayaan masyarakat dalam hal pendanaan/pembiayaan terhadap sektorsyariah, tidak terlepas dari suatu manajemen yang ada dalam perusahaan perbankan tersebut, khususnya terkait kepatuhan yang dijalankan.

Beberapa jenis dari produk ataupun pembiayaan dari jenis lembaga keuangan syariah atau dari jenis lembaga keuangan koperasi syariah memiliki kesamaan. Pembiayaan itu dibagi atas dua garis besar yaitu pembiayaan Natural Certainty Contract (NCC) dan pembiayaan Natural Uncertainty Contract (NUC). Adapun yang termasuk kedalam Pembiayaan NCC yaitu jual beli Murabahah, jual beli salam, jual beli isthiisna', ijarah, dan ijarah muntahiya bitttamlik (IBMT). Sedang yang termasuk dalam pembiayaan NUC yaitu dengan sistem bagi hasil adalah Mudharabah dan Musyarakah. Sistem bagi hasil terdapat dalam pembiayaan bank syariah salah satunya adalah Pembiayaam Mudharabah. ${ }^{2}$

Rivai dalam Purwanto (2011:15) menyatakan bahwa Pembiayaan mudharabah dan musyarakah ini memiliki perbedaan pada pembagian modal dan pengelolaan usaha $^{3}{ }^{3}$ serta pembagian keuntungan. Jika pembiayaan Mudharabah, pihak bank $100 \%$ menyumbangkan modal, sedangkan pihak nasabah hanya mengelola usaha. Pembagian keuntunganberdasarkan besar modal yang disumbangkan. Jika pembiayaan Musyarakah, pihak bank dan nasabah sama-sama

\footnotetext{
${ }^{1}$ Yaya, dkk (2009). Pengertian Bank Umum Syariah, Pengertian Bank Konvensional.

${ }^{2}$ Muhammad Rifqi, 2008, Akuntansi Keuangan Syariah, P3EI-Press, Yogyakarta.

${ }^{3}$ Purwanto, 2011, Pengertian dan Jenis Pendanaan, Pembiayaan Mudharabah dan Musyarakah, hlm.
} 
menyumbangkan modal dan mengelola usaha, biasanya sebesar 60\%:40\%. Pembagian keuntungan juga berdasarkan besar modal yang disertakan dalam usaha tersebut.

Menurut Kasmir, ${ }^{4}$ dalam bukunya dasar-dasar perbankan menyatakan bahwa pembiayaan adalah penyediaan uang atau tagihan yang dapat dipersamakan dengan itu, berdasarkan persetujuan atau kesepakatan antara bank dengan pihak lain yang mewajibkan pihak yang dibiayai untuk mengembalikan uang atau tagihan tersebut setelah jangka waktu tertentu dengan imbalan atau bagi hasil. Perbankan syariah memiliki cara pembiayaan yaitu dengan berdasarkan prinsip jual beli (al bai'), prinsip sewa-beli (ijarah muntahia bi tamlik), atau berdasarkan prinsip kemitraan (partnership) yaitu prinsip penyertaan dalam usaha (Musyarakah) atau prinsip bagi hasil (Mudharabah).

Penerapan sistem bagi hasil merupakan sistem yang memiliki resiko tinggi. Bagi hasil didapatkan dari pengelolaan dana yang digunakan untuk aktivitas usaha produktif. Dalam bank syariah bagi hasil di temui pada pembiayaan Mudharabah dan Musyarakah atau bisa disebut pembiayaan Natural Uncertainty Contract (NUC). Pembiayaan dalam perbankan syariah pada dasarnyan adalah sama dengan istilah kredit pada perbankan konvensional, yang berarti penyaluran dana. Disebut pembiayaan karena perbankan syariah menyediakan dana guna membiayai nasabah yang memerlukan dana dan layak untuk memperolehnya.

Profitabilitas secara umum terfokus pada hubungan antar hasil operasi seperti yang dilaporkan dalam laporan laba rugi dan sumber daya yang tersedia bagi perusahaan seperti yang dilaporkan dalam neraca. Mengetahui tingkat profitabilitas perusahaan juga sangat penting bagi sebuah manajer dalam mengambil keputusan. ${ }^{5}$

Berdasarkan hasil penelitian terdahulu, mengindikasikan adanya research gap dari variabel independen yang mempengaruhi ROA perusahaan, adapun dari variabel independen tersebut adalah pembiayaan Natural Certainty Contract (NCC) yaitu pembiayaan Murabahah, pembiayaan Salam, pembiayaan Istishna, Ijarah dan pembiayaan Natural Uncertainty Contract (NUC) yaitu pembiayaan Mudharabah dan Musyarakah.

Variabel pertama adalah pembiayaan Natural Certainty Contract (NCC) yang terdiri dari pembiayaan Murabahah, Salam, Istishna, dan Ijarah. Pembiayaan NCC ini adalah pembiayaan yang menggunakan prinsip jual beli. Semakin tinggi pembiayaan jual beli maka semakin tinggi profitabilitasnya karena pendapatan bank akan meningkat. Dalam penelitianya Nur Amalia (2016) menunjukan bahwa pembiayaan Murabahah, Istishna, dan Ijarah berpengaruh signifikan terhadap profitabilitas. Sedangkan dalam penelitian Indriani Laela Qodriasari (2014) menunjukan bahwa pembiayaan Murabahah dan Ijarah memiliki pengaruh negatif signifikan terhadap profitabilitas. Dengan adanya Research gap dari penelitian Nur Amalia (2016) dan Indriani Laela Qodriasari (2014), maka perlu dilakukan penelitian lanjutan mengenai pengaruh pembiayaan Murabahah, Istishna, dan Ijarah (pembiayaan Natural Certainty Contract (NCC)) terhadap profitabilitas.

\footnotetext{
${ }^{4}$ Kasmir, 2002, Pengertian Pembiayaan

${ }^{5}$ Dita Wulan Sari, 2013, "Pengaruh Pembiayaan Jual Beli, Pembiayaan Bagi Hasil, Financing To Deposit Ratio, dan Non Performing Financing Terhadap Profitabilitas Bank Umum Syariah 2009-2012". Universitas Diponegoro Semarang
} 
Variabel kedua yaitu pembiayaan Natural Uncertainty Contract (NUC). Dalam pembiayaan NUC menggunakan prinsip bagi hasil. Menurut Firdaus menyatakan bahwa semakin besar pembiayaan bagi hasil maka semakin besar profitabilitasnya, karena pendapatan dari pembiayaan bagi hasil akan mempengaruhi besarnya laba yang diperoleh bank, dan besarnya laba yang diperoleh akan mempengaruhi tingkat profitabilitasnya. Dalam penelitian Yesi Oktriani (2012) menunjukan bahwa pembiayaan Musyarakah dan Mudharabah secara parsial tidak berpengaruh signifikan terhadap profitabilitas. ${ }^{6}$ Sedangkan dalam penelitian Nuril Wahidah Rizqi,dkk (2016) menunjukan bahwa pembiayaan Mudharabah berpengaruh positif terhadap profitabilitas, sedangkan pembiayaan Musyarakah berpengaruh negatif terhadap profitabilitas. Dengan adanya Research gap dari penelitian Yesi Oktriani (2012) dan Nuril Wahidah Rizqi, dkk (2016), maka diperlukan penelitian lanjutan mengenai pengaruh pembiayaan Mudharabah dan Musyarakah (pembiayaan Natural Uncertainty Contract (NUC)) Terhadap Profitabilitas. $^{7}$

Sehingga peneliti ingin mengetahui tentang 1) Apakah pembiayaan Murabahah berpengaruh Terhadap Profitabilitas Bank Umum Syariah Periode 20132016? 2) Apakah pembiayaan Istishna berpengaruh Terhadap Profitabilitas Bank Umum Syariah periode 2013-2016? 3) Apakah Pembiayaan Ijarah berpengaruh Terhadap Profitabilitas Bank Umum Syariah periode 2013-2016? 4) Apakah pembiayaan Mudharabah berpengaruh Terhadap Profitabilitas Bank Umum Syariah periode 2013-2016? 5) Apakah Pembiayaan Musyarakah berpengaruh Terhadap Profitabilitas Bank Umum Syariah periode 2013-2016?

\section{Teori}

\section{Sharia Enterprise Theory}

Sharia Enterprise Theory merupakan Enterprise Theory yang telah diinternalisasi dengan nilai-nilai islam guna menghasilkan teori yang transcendental dan lebih humanis. ${ }^{8}$ Artinya teori yang mengakui adanya pertanggungjawaban tidak hanya kepada pemilik perusahaan saja melainkan kepada kelompok stakeholders yang lebih luas. ${ }^{9}$

Menurut Triyuwono (2003), akuntansi syariah tidak hanya sebagai bentuk akuntabilitas manajemen kepada pemilik perusahaan, tetapi juga sebagai akuntabilitas kepada stakeholders dan Tuhan. Pada dasarnya akuntansi syariah merupakan instrumen akuntabilitas yang dilakukan oleh manajemen kepada Tuhan (akuntabilitas vertikal), stakeholders, dan alam (akuntabilitas horizontal).

\section{Uncertainty Reduction Theory}

6 Yesi oktriani, "Pengaruh pembiayaan Musyarakah, mudharabah,dan murabahah terhadap profitabilitas (studi kasus pada PT. Bank Muamalat, Tbk.)".

7 Nuril Wahidah Rizqi, Noor Shodiq Askandar, dan Affifudin, "Analisis Pengaruh Pembiayaan Mudharabah, Musyarakah dan Ijarah terhadap profitabilitas bank syariah di indonesia”. Jurnal biasa

${ }^{8}$ Purwita Sari, 2011, Sharia Enterprise Theory

${ }^{9}$ Farida dan Veni Soraya Dewi, 2014, Arti dari Sharia Enterprise Theory 
Teori pengurangan ketidakpastian (Uncertainty Reduction Theory) ini terkadang disebut Initial Interaction Theory (Teori Interaksi Awal). Tujuan dari teori ini adalah untuk menjelaskan bagaimana komunikasi digunakan untuk mengurangi ketidakpastian diantara orang asing yang terlibat dalam pembicaraan satu sama lain untuk pertama kali. ${ }^{10}$ Oleh Berger dan Calabrese, teori ini kemudian sedikit diperjelas hingga muncul versi baru dari teori ini menyebutkan bahwa ada dua tipe ketidakpastian dari perjumpaan awal, yaitu :

1. Ketidakpastian Kognitif (Cognitive Uncertainty)

Merupakan tingkat ketidakpastian yang diasosiasikan dengan keyakinan dan sikap.

2. Ketidakpastian Perilaku (Behavioral Uncertainty)

Dilain pihak berkenaan dengan luasnya perilaku yang dapat diprediksikan dalam situasi yang diberikan.

Teori ini hampir sama dengan Teori informasi dari Claude E.Shannon dan Warren Weaver pada tahun 1949, menyatakan bahwa ketidakpastian ada ketika jumlah alternatif yang mungkin dalam sebuah situasi tinggi dan kemungkinan terjadinya alternatif-alternatif itu relatif setara. Sebaliknya, ketidakpastian menurun ketika alternatif-alternatif yang ada terbatas jumlahnya dan/atau terdapat sebuah alternatif yang biasanya dipilih.

\section{Perbankan Syariah}

Menurut UU RI no 10 tahun 1998 tentang perbankan, yang dimaksud dengan bank adalah badan usaha yang menghimpun dana dari masyarakat dalam bentuk simpanan dan menyalurkanya kepada masyarakat dalam bentuk kredit dan atau bentuk-bentuk lainya dalam rangka meningkatkan taraf hidup banyak orang. ${ }^{11}$

Menurut UU Perbankan Syariah Indonesia No. 21 tahun 2008, disebutkan bahwa bank terdiri dari dua jenis yaitu bank konvensional dan bank syariah. Bank konvensional adalah bank yang menjalankan kegiatan usahanya secara konvensional yang terdiri atas bank umum konvensional dan Bank Perkreditan Rakyat. Bank syariah adalah bank yang menjalankan kegiatan usahanya berdasarkan prinsip syariah yang terdiri atas Bank Umum Syariah (BUS) dan Bank Pembiayaan Rakyat Syariah (BPRS). BUS adalah bank syariah yang kegiatanya memberikan jasa dalam lalu lintas pembayaran. Dalam UU tersebut juga dikatakan bahwa bank konvensional yang hendak melaksanakan usaha syariah harus membentuk Unit Usaha Syariah (UUS) yang khusus beroperasi dengan sistem syariah. ${ }^{12}$ dua, yaitu :

Pendapat dari Ascarya dan Yumanita, ${ }^{13}$ Fungsi bank syariah terbagi menjadi

1) Sebagai badan usaha, yaitu bertugas menghimpun dana, menyalurkan dana dan menyediakan jasa keuangan dan non keuangan,

\footnotetext{
${ }^{10}$ Charles Berger dan Richard J Calabrese, 1975, Pengertian Uncertainty Reduction Theory

${ }^{11}$ Kasmir, 2008, Pengertian Perbankan Syariah

${ }^{12}$ Yaya, dkk., 2009, Pengertian Bank Umum Syariah, Pengertian Bank Konvensional

${ }^{13}$ Ascarya dan Yumanita, 2005, Pengertian Bank Syariah, Fungsi Bank Syariah

Bank Indonesia.Pengertian Pembiayaan, hlm. 4
} 
2) Sebagai badan sosial, bertugas untuk penghimpunan dan penyaluran zakat serta menyalurkan dana pinjaman kebajikan

Adapun Tujuan dari bank syariah yang hendak dicapai yaitu bank syariah berdiri untuk menggalakkan, memelihara dan mengembangkan jasa serta produkproduk perbankan yang berdasarkan prinsip-prinsip syariat islam. Bank syariah juga memiliki kewajiban untuk mendukung aktivitas investasi dan bisnis yang ada di lembaga keuangan sepanjang aktifitas tersebut tidak dilarang dalam islam. Selain itu, bank syariah harus lebih menyentuh kepentingan masyarakat kecil.

Kebutuhan dana untuk kegiatan utama bank diperoleh dari berbagai simpanan, sedangkan jika kebutuhan dana digunakan untuk investasi baru atau perluasan usaha maka diperoleh dari modal sendiri.

\section{Profitabilitas}

Profitabilitas merupakan rasio yang menghubungkan antara laba dari penjualan dan investasi. ${ }^{14}$ Analisis profitabilitas ini menggambarkan kinerja fundamental perusahaan ditinjau dari tingkat efisiensi dan efektifitas operasi perusahaan dalam memperoleh laba. ${ }^{15}$

Rasio profitabilitas (Profitabilty Ratios) adalah sekelompok rasio yang menunjukan kombinasi dari pengaruh likuiditas, manajemen aset, dan utang pada hasil operasi. ${ }^{16}$ Dari beberapa uraian diatas dapat disimpulkan bahwa rasio profitabilitas adalah rasio yang digunakan untuk mengukur aktifitas operasi perusahaan dalam menghasilkan laba atau keuntungan.

Rasio Rentabilitas sering disebut profitabilitas usaha. Menurut Lukman Dendawijaya Analisis Rasio Rentabilitas bank adalah alat untuk menganalisis atau mengukur tingkat efisiensi usaha dan profitabilitas yang dicapai oleh bank yang bersangkutan. ${ }^{17}$

rasio ini memiliki beberapa jenis rasio yang masing-masing memiliki maksud dan tujuan tersendiri. Adapun jenis-jenis rasio profitabilitas Menurut Lukman Dendawijaya adalah sebagai berikut $:^{18}$

1. Return On Assets (ROA)

ROA merupakan rasio yang memberikan informasi seberapa efisien suatu lembaga keuangan dalam melakukan kegiatan usahanya, karena rasio ini mengindikasikan seberapa besar keuntungan yang dapat diperoleh dari rat-rata setiap asetnya. ROA menunjukan kemampuan manajemen lembaga keuangan dalam mengelola aktiva yang tersedia untuk mendapatkan net income. Semakin besar ROA suatu bank menunjukan semakin besar keuntungan yang dicapai bank tersebut, mengindikasikan bahwa semakin baik pula posisi bank tersebut dari segi penggunaan asetnya. Rumus untuk mencari Return On Assets (ROA) adalah sebagai berikut :

$$
\text { Return On Assets }=\quad \frac{\text { Net Income }}{\text { Total Assets }} \quad \text { X 100\% }
$$

\footnotetext{
${ }^{14}$ Van Horne dan Wachowicz, 2009, Pengertian Profitabilitas.

${ }^{15}$ Harmono, 2009, Pengertian Profitabilitas

${ }^{16}$ Eugene F.Brigham dan Joel F.Houston, 2014, Dasar-Dasar Managemen Keuangan (Essensials Of Financial Management), Jakarta: Salemba Empat,.

${ }^{17}$ Lukman Dendawijaya, 2009, Analisis Rasio Profitabilitas, hlm. 118

${ }^{18}$ Ibid.,
} 
2. Return On Equity (ROE)

ROE adalah rasio laba bersih terhadap ekuitas biasa, mengukur tingkat pengembalian atas investasi pemegang saham biasa. Dapat juga dikatakan perbandingan antara laba bersih bank dengan modal sendiri. Rumus untuk menghitung Return On Equity (ROE) adalah sebagai berikut :

$$
\text { Return On Equity }=\frac{\text { Net Income }}{\text { Equity Capital }} \quad X 100 \%
$$

\section{Net Profit Margin (NPM)}

Net Profit Margin adalah rasio yang menggambarkan tingkat keuntungan (laba) yang diperoleh bank dibandingkan dengan pendapatan yang diterima dari kegiatan operasionalnya. Rumus untuk menghitung Net Profit Margin (NPM) adalah sebagai berikut :

$$
\text { Net Profit Margin }=\quad \frac{\text { Net Income }}{\text { Operating Income }} \quad X 100 \%
$$

4. BOPO (Biaya Operasional Pendapatan Operasional)

Rasio Biaya Operasional adalah rasio perbandingan antar biaya operasional dan pendapatan operasional. Rasio ini digunakan untuk mengukur tingkat efisiensi dan kemampuan bank dalam melakukan kegiatan operasinyaa. Rumus untuk menghitung BOPO adalah sebagai berikut :

$$
\mathrm{BOPO}=\frac{\text { Biaya Operasional }}{\text { Pendapatan Operasional }} \quad \mathrm{X} 100 \%
$$

\section{Pembiayaan Syariah}

Berdasarkan pasal 1 ayat 12 UU No. 10 tahun 1998 tentang perbankan, pembiayaan berdasarkan prinsip syariah ialah "penyediaan uang atau tagihan yang dipersamakan dengan itu berdasarkan persetujuan atau kesepakatan antara bank dengan pihak lain yang mewajibkan pihak yang dibiayai untuk mengembalikan uang atau tagihan tersebut setelah jangka waktu tertentu dengan imbalan atau bagi hasil".

\section{a. Pembiayaan Natural Certainty Contract (NCC)}

Natural Certainty Countract adalah kontrak yang menentukan secara pasti nilai nominal dari keuntungan di awal kontrak perjanjian yang artinya memberikan kepastian pengembalian atau hasil. Saat ini pembiayaan Natural Certainty Contract (NCC) sangat dominan digunakan oleh perbankan syariah jika dibandingkan dengan pembiayaan Natural Uncertainty Contract (NUC).

Adapun yang termasuk dalam Pembiayaan Natural Certainty Contract (NCC) adalah jual beli Murabahah, jual beli Salam, jual beli Istishna', Ijarah dan Ijarah Muttahiya Bittamlik (IBMT). Penjelasan dari masing-masing Pembiayaan tersebut adalah sebagai berikut :

1. Murabahah

Murabahah merupakan salah satu prinsip jual beli yang dijalankan bank syariah tanpa mengenal riba. Murabahah adalah akad jual beli barang pada harga asal dengan tambahan keuntungan yang disepakati.

2. Salam 
Transaksi Salam dalah pesanan barang yang disebutkan sifat-sifatnya, yang dalam majelis itu pemesan barang menyerahkan uang seharga barang pesanan yang barang pesanan tersebut menjadi tanggungan penerima pesanan. $^{19}$

3. Istishna'

Adalah akad jual beli antara pemesan atau pembeli (mustashni) dengan produsen atau penjual (Shani) barang yang diperjualbelikan harus dibuat terlebih dahulu dengan kriteria yang jelas. Istishna' hampir sama dengan Salam, bedanya hanya terletak pada cara pembayaranya.

4. Ijarah

Ijarah adalah pemindahan hak guna atas barang dan jasa, melalui upah pembayaran sewa, tanpa diikuti dengan pemindahan kepemilikan atas barang itu sendiri. Ijarah berarti leasecontractdimana suatu bank atau lembaga keuangan menyewakan peralatan (equipment) kepada salah satu nasabahnya berdasarkan pembebanan biaya yang sudah ditemukan secara pasti sebelumnya (fixed charge). Pada akhir masa sewa bank bisa saja menjual barang yang disewakanya kepada nasabah. Karena itu dikenal dengan ijarah muntahiyyah bittamlik (sewa yang diikuti dengan berpindahnya kepemilikan).

\section{b. Pembiayaan Natural Uncertainty Contract (NUC)}

Pembiayaan Natural Uncertainty Countract adalah kontrak yang dilakukan dengan tidak menyepakati nominal keuntungan yang akan diterima melainkan menyepakati nisbah bagi hasil yang diterima sehingga tidak ada kepastian nilai nominal yang akan diterima karena tergantung pada keuntungan usaha. Dalam Pembiayaan Natural Uncertainty Contract (NUC), pihak-pihak yang bertransaksi saling mencampur assetnya (baik real asset maupun financial assets) menjadi satu kesatuan, kemudian mengandung risiko bersama-sama untuk mendapatkan keuntungan. ${ }^{20}$

Pembiayaan Natural Uncertainty Contract (NUC) tidak memberikan kepastian dalam pengambilan dan hasil hanya berdasarkan kesepakatan yang disebut nisbah. Adapun yang termasuk ke dalam Pembiayaan Natural Uncertainty Contract (NUC) adalah Pembiayaan dengan sistem bagi hasil yaitu Mudharabah dan Musyarakah.

1. Mudharabah

adalah kerja sama usaha antara dua pihak, dimana pihak pertama sebagai (sahibul maal) sebagai pemilik modal menyediakan seluruh modalnya (100\%) untuk dikelola oleh pihak kedua (mudharib) sebagai pengelola dengan suatu perjanjian pembagian keuntungan.

2. Musyarakah

adalah pembiayaan dengan penyertaan modal, dimana dua atau lebih mitra berkontribusi untuk memberikan modal suatu investasi. Kata lain pembiayaan musyarakah merupakan perjanjian kerja sama antara dua pihak atau lebih pemilik modal (uang atau barang) untuk membiayai suatu usaha dimana masing-masing pihak berhak atas segala sesuatu keuntungan dari usaha tersebut dibagi berdasar persetujuan sesuai porsi masing-masing.

\footnotetext{
${ }^{19}$ Muhammad Rifqi, 2008, Akuntansi Keuangan Syariah, Yogyakarta: P3EI-Press.

${ }^{20}$ Ahmad Ifham, 2010, Buku Pintar Ekonomi Syariah.
} 


\section{Metode}

Jenis penelitian yang digunakan dalam penelitian ini adalah bersifat deskriptif kuantitatif yang artinya dimana data yang didapatkan dari sumber penelitian diolah ke dalam sistem komputerisasi sehingga nantinya diharapkan hasilnya akan lebih akurat. Dalam hal ini adalah mencari kebenaran dari data yang didapatkan, apakah pembiayaan Natural Certainty Contract (NCC) dan Pembiayaan Natural Uncertainty Contract (NUC) memberi pengaruh atau tidak pada Profitabilitas dari Bank Umum Syariah di Indonesia periode (2013-2016).

Penelitian ini menggunakan data kuantitatif yaitu laporan keuangan bagian laba rugi maupun Laporan Posisi Keuangan dari laporan keuangan triwulan yang ada di daftar Otoritas Jasa Keuangan (OJK) terdiri dari delapan Bank Umum Syariah periode 2013-2016.

Sumber data yang digunakan di dalam penelitian ini adalah data Sekunder, yakni laporan keuangan triwulan milik Bank Umum Syariah yang telah ada di daftar Otoritas Jasa Keuangan (OJK) periode 2013-2016 ${ }^{21}$ atau bisa di website Bank Indonesia.

Sedangkan Populasi dalam penelitian ini adalah seluruh Bank Umum Syariah yang terdaftar di Otoritas Jasa Keuangan (OJK) periode 2013-2016 yang berjumlah 11 bank.

Selanjutnya, metode pengambilan sampel dalam penelitian ini menggunakan metode Purposive sampling. Purposive Sampling yaitu pengambilan sampel non probability dimana metode ini menetapkan bahwa setiap elemen tidak memiliki kesempatan yang sama untuk menjadi sampel penelitian, harus memenuhi syarat atau kriteria tertentu yang dapat digunakan sebagai sampel untuk penelitian. ${ }^{22}$

Adapun kriteria dari penentuan sampel dalam penelitian ini adalah :

1) Bank Umum Syariah di Indonesia

2) Bank yang diteliti masih beroperasi pada periode waktu penelitian yaitu periode 2013-2016

3) Bank yang diteliti menyediakan laporan keuangan Triwulan

4) Bank yang diteliti mengalami kenaikan pendapatan margin murabahah selama periode waktu penelitian. ${ }^{23}$

Proses pemilihan sampel yang dilakukan berdasarkan kriteria-kriteria tersebut adalah sebagai berikut :

Tabel 3.2

Proses Pemilihan Sampel Penelitian Periode 2013 - 2016

\begin{tabular}{|l|c|}
\hline \multicolumn{1}{|c|}{ Keterangan } & Satuan \\
\hline Bank Umum Syariah di Indonesia tahun 2016 & 11 \\
\hline Bank Umum Syariah yang tidak menyajikan laporan & $\mathbf{( 0 )}$ \\
\hline
\end{tabular}

${ }^{21}$ www.ojk.go.id

22 Nur Amalia, Fidiana, 2016, "Struktur Pembiayaan dan Pengaruhnya terhadap Profitabilitas Bank Muamalat Indonesia dan Bank Syariah Mandiri". Jurnal Ilmu dan Riset Akuntansi, volume 5, No 5, Mei 2016, ISSN 2460-0585, Sekolah Tinggi Ilmu Ekonomi Indonesia (STIESIA) Surabaya.

${ }^{23}$ Liza Nur Hidayah, "pengaruh pembiayaan Natural Uncertainty Contract (NUC) dan Natural Certainty Contract (NCC) terhadap profitabilitas bank umum syariah periode 2008-2012". 


\begin{tabular}{|l|c|}
\hline Triwulan & \\
\hline $\begin{array}{l}\text { Bank Umum Syariah yang tidakmenggunakan } \\
\text { transaksi Istishna selama periode penelitian }\end{array}$ & $\mathbf{( 5 )}$ \\
\hline Bank Umum Syariah yang terpilih menjadi sampel & $\mathbf{6}$ \\
\hline
\end{tabular}

Sumber : www.ojk.go.id (Diolah Penulis)

Tabel 3.2 menunjukan bahwa dari 11 Bank Umum Syariah yang terdaftar di Otoritas Jasa Keuangan (OJK) pada tahun 2013-2016 terdapat 6 Bank Umum Syariah yang secara konsisten memenuhi karakteristik sampel yang ditetapkan. Maka sampel yang digunakan dalam penelitian ini adalah data laporan keuangan Triwulan dari tahun 2013 sampai dengan 2016 pada 6 Bank Umum Syariah di Indonesia, yaitu Bank BRI Syariah, Bank Muamalat Indonesia, Bank Mandiri Syariah, Bank Bukopin Syariah, Bank Jabar Banten Syariah, dan Maybank Syariah. Berdasarkan Tabel 3.2 menunjukan keseluruhan jumlah yang ditetapkan sebagai sampel selama periode penelitian yaitu 6 bank selama 4 tahun periode pengamatan sehingga 24 sampel terpilih. Jumlah laporan keuangan yang digunakan yaitu 96 laporan Laba Rugi dari 24 sampel yang ditetapkan.

Teknik pengumpulan data yang digunakan oleh peneliti adalah dengan menggunakan beberapa metode yaitu :

1) Studi Kepustakaan

Metode ini digunakan untuk menggali dasar-dasar teori yang terkait dengan Pembiayaan Natural Certainty Contract (NCC) dan Pembiayaan Natural Uncertainty Contract (NUC), pendapat para ahli, dan Profitabilitas perbankan syariah.

2) Pengamatan

Penelitian ini termasuk dalam Observational Research, karena penelitian ini dilakukan dengan pengamatan pada data sekunder yang telah tersedia. Setiap data yang didapat dari berbagai sumber diamati dan dianalisa terkait pembiayaan Natural Certainty Contract (NCC) dan Pembiayaan Natural Uncertainty Contract (NUC), memberi pengaruh secara signifikan atau tidak memberi pengaruh pada Profitabilitasnya. Mengamati apakah selama operasionalnya Bank Syariah mendapatkan dana pembiayaan murni dari pembiayaan Natural Certainty Contract (NCC) dan pembiayaan Natural Uncertainty Contract (NUC).

Metode analisis data yang digunakan adalah dengan menggunakan Uji Asumsi Klasik, Analisis Regresi linier Berganda, Uji Hipotesis yaitu Uji Parsial (Uji t)).

\section{Uji Asumsi Klasik}

Uji Asumsi Klasik ini digunakan untuk mengetahui nilai-nilai koefisienya agar tidak biasa. Uji asumsi klasik adalah analisis yang dilakukan untuk menilai apakah di dalam sebuah model regresi linear ordinary least square (OLS). Di dalam model regresi ini, ada beberapa syarat yang harus dipenuhi agar model peramalan yang dibuat menjadi valid sebagai alat peramalan. Syaratsyarat tersebut apabila dipenuhi semuanya, maka model regresi linear tersebut 
dikatakan BLUE (Best Linear Unbiased Estimation). Regresi OLS ini ada 2 macam yaitu, regresi linear sederhana dan regresi linear berganda. ${ }^{24}$

\section{Analisis Regresi Linier Berganda}

Adapun rumus regresi linier berganda adalah sebagai berikut :

$$
\begin{aligned}
& \mathrm{Y}=\mathrm{a}+\beta_{1} \mathrm{MDH}+\beta_{2} \mathrm{MSH}+\beta_{3} \mathrm{MRH}+\beta_{4} \mathrm{IST}+\beta_{5} \mathrm{IJR}+\mathrm{e} \\
& \text { Keterangan : } \\
& \mathrm{Y} \quad=\text { Tingkat Profitabilitas (ROA) } \\
& \text { A } \quad=\text { Bilangan Konstanta } \\
& \beta=\text { Koefisien regresi dari tiap variabel } \\
& \mathrm{MDH}=\text { Pembiayaan Mudharabah (dalam rupiah) } \\
& \text { MSH = Pembiayaan Musyarakah (dalam rupiah) } \\
& \text { MRH = Pembiayaan Murabahah (dalam rupiah) } \\
& \text { IST = Pembiayaan Istishna (dalam rupiah) } \\
& \text { IJR = Pembiayaan Ijarah (dalam rupiah) } \\
& \mathrm{e} \quad=\text { error term }
\end{aligned}
$$

\section{Uji Hipotesis}

\section{Uji Pengaruh Parsial (Uji t)}

Uji ini digunakan untunk menguji pengaruh variabel independen terhadap variabel dependen secara parsial. Menurut Sugiyono uji t ini digunakan untuk mengetahui masing-masing sumbangan variabel bebas secara parsial terhadap variabel terikat, menggunakan uji masing-masing koefisien regresi variabel bebas apakah mempunyai pengaruh yang bermakna atau tidak terhadap variabel terikat. ${ }^{25}$ Sedangkan menurut pendapat Ghozali (2005) menyatakan bahwa Uji statistik t pada dasarnya untuk menunjukan seberapa jauh pengaruh satu variabel independen secara individual dalam menerangkan variabel dependen. Analisis data dilakukan dengan langkah-langkah sebagai berikut :

1. Menganalisis pembiayaan Natural Certainty Contract (NCC) dan Pembiayaan Natural Uncertainty Contract (NUC) dalam kegiatan operasionalnya,

2. Menginterpretasikan hasil analisis dan penemuan-penemuan baru dan menilai adakah pengaruh yang diberikan atas kegiatan pembiayaan Natural Certainty Contract (NCC) dan Pembiayaan Natural Uncertainty Contract (NUC) ini terhadap Profitabilitas Bank Umum Syariah periode (2013-2016)

\section{B. Pembahasan}

\footnotetext{
${ }^{24}$ Dita Wulan Sari, 2013, "Pengaruh Pembiayaan Jual Beli, Pembiayaan Bagi Hasil, Financing To Deposit Ratio, dan Non Performing Financing Terhadap Profitabilitas Bank Umum Syariah 2009-2012”. Universitas Diponegoro Semarang

${ }^{25}$ Sugiyono, 2011. Metode Penelitian Kuantitatif, Kualitatif, dan R\&D. Bandung: Alfabeta, hlm. 194
} 


\section{Uji Asumsi Klasik}

\section{a. Uji Normalitas}

Jika dilihat dari scatter diagram, data variabel ini menyebar normal. Hal ini dapat dilihat dari penyebaran titik-titik data berada di sekitar garis lurus diagonal mendekati $45^{\circ}$, seperti terlihat pada gambar berikut ini.

\section{Gambar 4.1}

\section{Scatter Diagram Uji Normalitas}

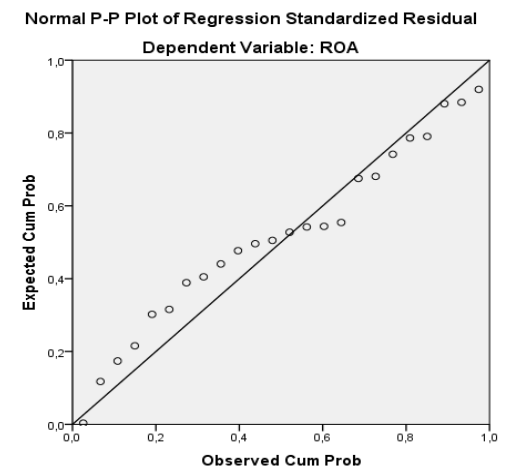

Sumber : Data diolah menggunakan SPSS 22

\section{b. Uji Multikolinieritas}

Gambar 4.2

Hasil uji multikolinieritas

\begin{tabular}{|c|c|c|c|c|c|c|c|}
\hline \multirow[b]{3}{*}{ Model } & \multicolumn{5}{|c|}{ Coefficients $^{\mathrm{a}}$} & \multirow{2}{*}{\multicolumn{2}{|c|}{$\begin{array}{c}\text { Collinearity } \\
\text { Statistics }\end{array}$}} \\
\hline & \multicolumn{2}{|c|}{$\begin{array}{c}\text { Unstandardized } \\
\text { Coefficients }\end{array}$} & $\begin{array}{c}\text { Standar } \\
\text { dized } \\
\text { Coeffici } \\
\text { ents } \\
\end{array}$ & & & & \\
\hline & B & $\begin{array}{l}\text { Std. } \\
\text { Error }\end{array}$ & Beta & $\mathrm{T}$ & Sig. & $\begin{array}{c}\text { Toleran } \\
\text { ce }\end{array}$ & VIF \\
\hline (Constant) & 12,709 & 7,498 & & $-1,695$ &, 107 & & \\
\hline Murabahah & ,273 &, 545 & , 103 &, 501 & ,623 &, 831 & 1,204 \\
\hline Ijarah &, 753 & , 462 & ,404 & 1,632 &, 120 &, 577 & 1,734 \\
\hline Istishna & ,262 & ,205 & ,290 & 1,279 & ,217 & 691 & 1,448 \\
\hline Mudharabah &,- 428 & ,346 &,- 346 & $-1,238$ & ,232 &, 454 & 2,202 \\
\hline Musyarakah &, 424 & ,372 & ,347 & 1,139 & ,270 & ,383 & 2,612 \\
\hline
\end{tabular}

a. Dependent Variable: ROA

Berdasarkan tabel di atas dapat disimpulkan bahwa hubungan antara pembiayaan Murabahah, Ijarah, Istishna', Mudharabah dan 
Musyarakah adalah tidak sempurna (tidak mengandung multikolinieritas) atau tidak ada Multikolinieritas antar variabel bebas dalam model regresi tersebut. Hal ini dapat dilihat dari nilai VIF dari kelima pembiayaan tersebut yaitu Murabahah (1,204), Ijarah (1,734), Istishna' (1,448), Mudharabah(2,202), dan Musyarakah $(2,612)$ yang berarti berada di bawah nilai VIF normal sebesar 10.

\section{c. Uji Heterokedastisitas}

Gambar 4.3

hasil uji heterokedastisitas

Coefficients $^{\mathrm{a}}$

\begin{tabular}{|c|c|c|c|c|c|}
\hline \multirow[b]{2}{*}{ Model } & \multicolumn{2}{|c|}{$\begin{array}{c}\text { Unstandardized } \\
\text { Coefficients }\end{array}$} & \multirow{2}{*}{$\begin{array}{c}\text { Standardized } \\
\text { Coefficients } \\
\text { Beta }\end{array}$} & \multirow[b]{2}{*}{$\mathrm{t}$} & \multirow[b]{2}{*}{ Sig. } \\
\hline & $\mathrm{B}$ & Std. Error & & & \\
\hline $1 \quad$ (Constant) & $-12,709$ & 7,498 & & $-1,695$ & 107 \\
\hline Musyarakah & ,424 & ,372 & 347, & 1,139 & ,270 \\
\hline Mudharabah &,- 428 & ,346 &,- 346 & $-1,238$ & ,232 \\
\hline Istishna & ,262 & ,205 & ,290 & 1,279 & ,217 \\
\hline Ijarah & ,753 & , 462 & ,404 & 1,632 & , 120 \\
\hline Murabahah & ,273 &, 545 & ,103 &, 501 & 623 \\
\hline
\end{tabular}

a. Dependent Variable: ROA

\section{Sumber : Data diolah menggunakan SPSS 22}

\section{d. Uji Autokorelasi}

Berdasarkan hasil uji, nilai Durbin Watson hitung (DW) adalah sebesar 1,756. Jika dilihat dari rentang nilai antara batas atas (dU) dan batas bawah (dL), nilai tersebut berada pada interval $\mathrm{dL} \leq \mathrm{d} \leq$ Du yaitu $0,925 \leq 1,756$ $\leq 1,902$. Hal tersebut berarti uji autokorelasi ini tidak memenuhi asumsi atau tidak menghasilkan kesimpulan yang pasti. Seperti yang terlihat pada gambar di bawah ini :

Gambar 4.4

hasil uji Autokorelasi

\begin{tabular}{|l|c|r|r|r|c|}
\hline Model Summary \\
Model & R & R Square & $\begin{array}{c}\text { Adjusted R } \\
\text { Square }\end{array}$ & $\begin{array}{c}\text { Std. Error of } \\
\text { the Estimate }\end{array}$ & $\begin{array}{c}\text { Durbin- } \\
\text { Watson }\end{array}$ \\
\hline 1 &, $602^{\mathrm{a}}$ &, 362 &, 185 & 12,25080 & 1,756 \\
\hline
\end{tabular}

a. Predictors: (Constant), Murabahah, Mudharabah, Ijarah, Istishna, Musyarakah

b. Dependent Variable: ROA

\section{Analisis Regresi Linear Berganda}

Hasil uji menggunakan Analisis Regresi Linier Berganda dapat dilihat pada gambar tabel dibawah ini : 
Gambar 4.5

Hasil uji Analisis Regresi Linier Berganda

\begin{tabular}{|c|c|c|c|c|c|c|}
\hline \multicolumn{7}{|c|}{ Coefficients $^{\mathrm{a}}$} \\
\hline \multirow{2}{*}{\multicolumn{2}{|c|}{ Model }} & \multicolumn{2}{|c|}{$\begin{array}{c}\text { Unstandardized } \\
\text { Coefficients }\end{array}$} & \multirow{2}{*}{$\begin{array}{c}\text { Standar } \\
\text { dized } \\
\text { Coeffici } \\
\text { ents } \\
\text { Beta }\end{array}$} & \multirow[b]{2}{*}{$\mathrm{T}$} & \multirow[b]{2}{*}{ Sig. } \\
\hline & & $\mathrm{B}$ & $\begin{array}{l}\text { Std. } \\
\text { Error }\end{array}$ & & & \\
\hline & (Constant) & $-12,709$ & 7,498 & & $-1,695$ &, 107 \\
\hline & $\begin{array}{l}\text { Musyarak } \\
\text { ah }\end{array}$ &, 424 & ,372 &, 347 & 1,139 & ,270 \\
\hline & $\begin{array}{l}\text { Mudharab } \\
\text { ah }\end{array}$ &,- 428 & ,346 &,- 346 & $-1,238$ & ,232 \\
\hline & Istishna &, 262 & ,205 &, 290 & 1,279 & ,217 \\
\hline & Ijarah &, 753 & ,462 &, 404 & 1,632 &, 120 \\
\hline & $\begin{array}{l}\text { Murabaha } \\
\mathrm{h}\end{array}$ &, 273 &, 545 & , 103 &, 501 & ,623 \\
\hline
\end{tabular}

a. Dependent Variable: ROA

Dari hasil uji menggunakan Analisis regresi linier berganda seperti yang terlihat dalam gambar di atas menggambarkan hubungan data $\mathrm{X}$ dan $\mathrm{Y}$ yang dengan persamaan sebagai berikut :

$\mathrm{Y}=-12,709+0,273 \mathrm{MRH}+0,753 \mathrm{IJR}+0,262 \mathrm{ISH}-0,428 \mathrm{MDH}+0,424$ $\mathrm{MSH}$

Keterangan :

$\mathrm{Y}=$ Tingkat Profitabilitas (ROA)

$\mathrm{MDH}=$ Pembiayaan Mudharabah (dalam rupiah)

MSH = Pembiayaan Musyarakah (dalam rupiah)

MRH = Pembiayaan Murabahah (dalam rupiah)

IST $=$ Pembiayaan Istishna (dalam rupiah)

$\mathrm{IJR}=$ Pembiayaan Ijarah (dalam rupiah)

\section{Uji Hipotesis}

a. Uji Pengaruh Parsial (uji t) ini:

Hasil uji t pada penelitian ini dapat dilihat pada gambar tabel di bawah

Gambar 4.6

Hasil uji parsial (uji t)

Coefficients $^{\mathrm{a}}$ 


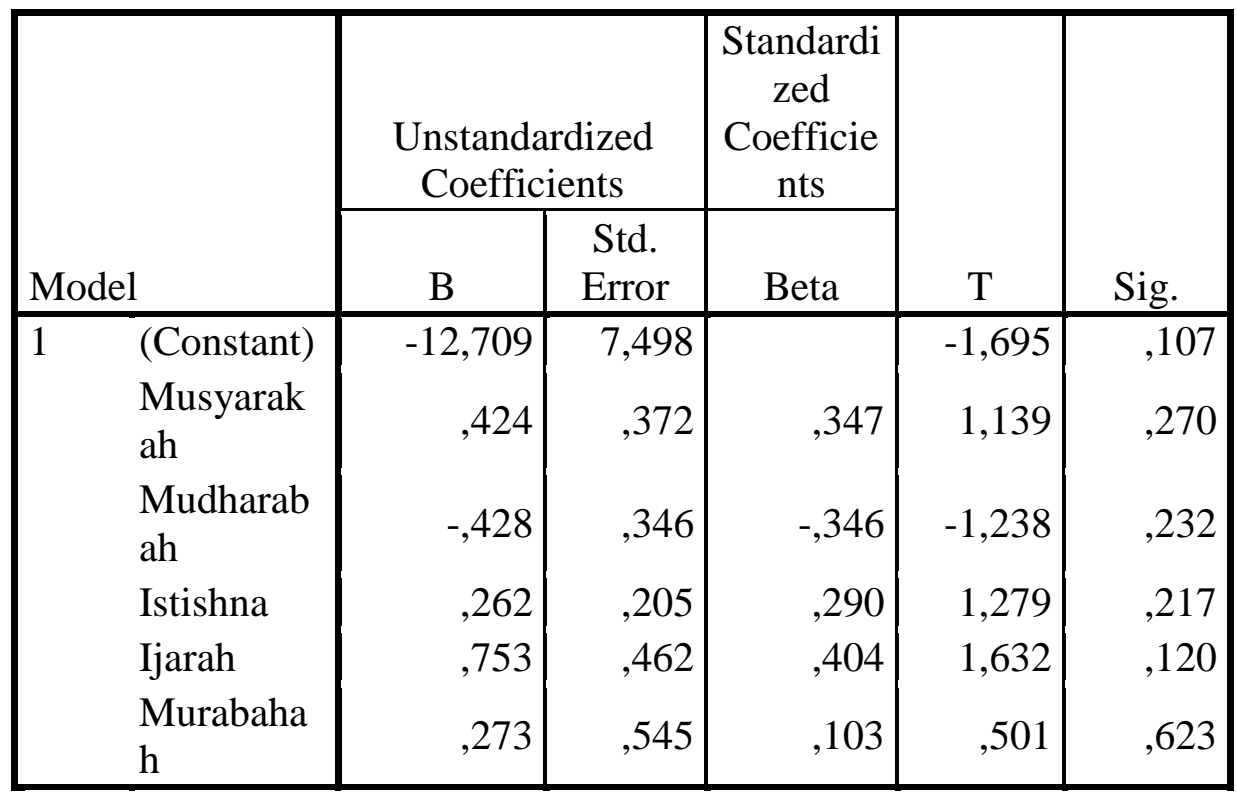

a. Dependent Variable: ROA

\section{H1 : Pembiayaan Murabahah berpengaruh positif signifikan terhadap profitabilitas (ROA).}

Profitabilitas menggambarkan kinerja fundamental perusahaan ditinjau dari tingkat efisiensi dan efektifitas operasi perusahaan dalam memperoleh laba. Dimana ketika tingkat profitabilitas naik maka baik pula kinerja keuangan dari suatu perusahaan tersebut. Pernyataan hipotesis pertama bahwa variabel pembiayaan Murabahah berpengaruh positif signifikan terhadap profitabilitas tidak terbukti. Hal ini dapat dilihati dari hasil uji t untuk hipotesis pertama menunjukan bahwa $\mathrm{Ho}_{1}$ diterimadan $\mathrm{Ha}_{1}$ tidak dapat diterima, hal ini ditunjukan oleh variabel pembiayaan Murabahah memiliki nilai t $0,501<1,734$ dan nilai signifikansi 0,623>0,05 yang berarti secara parsial variabel pembiayaan Murabahah tidak berpengaruh signifikan terhadap profitabilitas. hasil

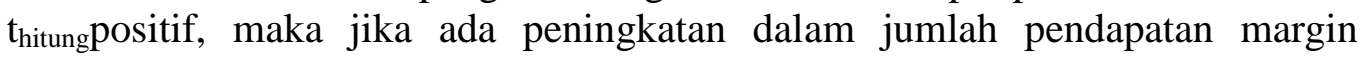
murabahah maka akan meningkatkan pula tingkat profitabilitasnya.

Dari hasil penelitian yang sudah dilakukan diketahui bahwa dalam setiap periode pelaporan keuangan ditemukan pembiayaan Murabahah selalu mengalami kenaikan selama periode penelitian karena pembiayaan Murabahah lebih diminati oleh masyarakat dibanding dengan pembiayaan syariah yang lainya. Meskipun selama periode penelitian pembiayaan Murabahah selalu mengalami kenaikan namun tidak berarti sepenuhnya mempengaruhi tingkat profitabilitas perusahaan. Tinggi rendahnya margin keuntungan Murabahah tidak berarti bahwa akan memberi pengaruh pada tingkat profitabilitas.

Hasil penelitian ini tidak konsisten dengan hasil penelitian sebelumnya yang dilakukan oleh Yesi Oktriani yang menyatakan bahwa pembiayaan 
Murabahah secara parsial berpengaruh positif dan signifikan terhadap profitabilitas. ${ }^{26}$

\section{H2 : Pembiayaan Ijarah berpengaruh positif signifikan terhadap profitabilitas (ROA).}

Pernyataan hipotesis kedua bahwa pembiayaan Ijarah berpengaruh positif signifikan terhadap profitabilitas tidak terbukti. Hal ini dapat diketahuimelalui hasil uji $\mathrm{t}$ untuk hipotesis kedua menunjukan bahwa $\mathrm{Ho}_{2}$ diterimadan $\mathrm{Ha}_{2}$ tidak dapat diterima, hal ini ditunjukan oleh variabel pembiayaan Ijarah memiliki nilai $\mathrm{t} 1,632<1,734$ dan nilai signifikansi $0,120>0,05$ yang berarti secara parsial variabel pembiayaan Ijarah tidak berpengaruh signifikan terhadap profitabilitas. Hasil $t_{\text {hitung }}$ positif, maka jika ada peningkatan dalam jumlah pendapatan margin Ijarah maka akan meningkatkan pula tingkat profitabilitasnya.

Dari hasil penelitian yang sudah dilakukan diketahui bahwa dalam setiap periode pelaporan keuangan ditemui untuk pembiayaan Ijarah fluktuatif naik turun. Bahkan untuk beberapa bank yang menjadi sampel penelitian untuk pembiayaan Ijarah sendiri selalu mengalami penurunan, hal ini disebabkan karena pembiayaan Ijarah kurang diminati oleh masyarakat luas, kurangnya sosialisasi dari pihak perbankan itu sendiri. Selain itu pembiayaan Ijarah untuk beberapa bank syariah hanya digunakan sebagai pelengkap jenis produk dan layanan saja. Jadi, meskipun margin sewa Ijarah fluktuatif naik turun bukan berarti bahwa pembiayaan Ijarah dapat mempengaruhi tingkat profitabilitas perusahaan.

Hal ini didukung oleh penelitian sebelumnya yang dilakukan oleh Nuril Wahidah Rizqi, dkk (2016) yang menyatakan bahwa Pembiayaan Ijarah berpengaruh positif tidak signifikan terhadap profitabilitas. ${ }^{27}$

\section{H3 : Pembiayaan Istishna berpengaruh positif signifikan terhadap profitabilitas (ROA).}

Pernyataan hipotesis ketiga bahwa pembiayaan Istishna berpengaruh positif signifikan terhadap profitabilitas tidak terbukti. Hal ini dapat diketahui melalui hasil uji t untuk hipotesis ketiga menunjukan bahwa Ho3 diterimadan Ha3 tidak dapat diterima, hal ini ditunjukan oleh variabel pembiayaan Istishna memiliki nilai t $1,279<1,734$ dan nilai signifikansi $0,217>0,05$ yang berarti secara parsial variabel pembiayaan Istishna tidak berpengaruh signifikan terhadap profitabilitas. Hasil thitungpositif, maka jika ada peningkatan dalam jumlah pendapatan margin Istishna' maka akan meningkatkan pula tingkat profitabilitasnya.

Dari hasil penelitian yang sudah dilakukan diketahui bahwa dalam setiap periode pelaporan keuangan ditemukan untuk variabel pembiayaan Istishna' fluktuatif naik turun selama periode penelitian. Hal ini disebabkan karena

\footnotetext{
26 Yesi oktriani, "Pengaruh pembiayaan Musyarakah, mudharabah,dan murabahah terhadap profitabilitas (studi kasus pada PT. Bank Muamalat, Tbk.)”.

${ }^{27}$ Nuril Wahidah Rizqi, Noor Shodiq Askandar, dan Affifudin, “Analisis Pengaruh Pembiayaan Mudharabah, Musyarakah dan Ijarah terhadap profitabilitas bank syariah di indonesia".
} 
pembiayaan Istishna' biasanya digunakan untuk produk layanan pertanian yang sistemnya dengan cara pemesanan terlebih dahulu. Hanya beberapa masyarakat saja yang berminat menggunakan produk layanan ini, selain itu pembiayaan Istishna' dibanding pembiayaan yang lain kurang diminati dimasyarakat umum.

Hasil penelitian ini tidak konsisten dengan hasil penelitian sebelumnya yang dilakukan oleh Liza Nur Hidayah (2012) yang menyatakan bahwa pembiayaan Istishna' berpengaruh positif signifikan terhadap profitabilitas bank umum syariah periode $2008-2012 .^{28}$

\section{H4 : Pembiayaan Mudharabah berpengaruh positif signifikan terhadap profitabilitas (ROA).}

Pernyataan hipotesis ke empat bahwa pembiayaan Mudharabah berpengaruh positif signifikan terhadap profitabilitas tidak terbukti. Hal ini dapat diketahui melalui hasil uji t untuk hipotesis ke empat menunjukan bahwa $\mathrm{Ho}_{4}$ diterimadan $\mathrm{Ha}_{4}$ tidak dapat diterima, hal ini ditunjukan oleh variabel pembiayaan Mudharabah memiliki nilai $t-1,238>1,734$ dan nilai signifikansi 0,232>0,05 yang berarti secara parsial variabel pembiayaan Mudharabah tidak berpengaruh signifikan terhadap profitabilitas. Hasil $t_{\text {hitung }}$ negatif, maka tidak berarti bahwa jika ada peningkatan dalam jumlah pendapatan margin Mudharabah maka akan meningkatkan pula tingkat profitabilitasnya.

Dari hasil penelitian yang sudah dilakukan diketahui bahwa dalam setiap periode pelaporan keuangan ditemukan untuk variabel pembiayaan Mudharabah mengalami kenaikan dan juga penurunan. Hal ini disebabkan karena pembiayaan Mudharabah memiliki resiko yang lebih tinggi dibanding dengan pembiyaan yang lain. Pembiayaan Mudharabah lebih dikenal masyarakat luas namun minat dari masyarakat masih rendah.

Hasil penelitian ini tidak konsisten dengan hasil penelitian sebelumnya yang dilakukan oleh Nuril Wahidah Rizqi, dkk (2016) yang menyatakan bahwa pembiayaan Mudharabah berpengaruh positif signifikan terhadap profitabilitas. ${ }^{29}$ Tidak terdukungnya variabel pembiayaan Mudharabah terhadap profitabilitas sejalan dengan hasil penelitian yang dilakukan oleh Yesi Oktriani (2012) yang menyatakan bahwa pembiayaan Mudharabah secara parsial tidak berpengaruh signifikan terhadap profitabilitas. ${ }^{30}$

\section{H5 : Pembiayaan Musyarakah berpengaruh positif signifikan terhadap profitabilitas (ROA).}

Pernyataan hipotesis kelima bahwa pembiayaan Musyarakah berpengaruh positif signifikan terhadap profitabilitas tidak terbukti. Hal ini dapat diketahui melalui hasil uji t untuk hipotesis kelima menunjukan bahwa $\mathrm{Ho}_{5}$ diterimadan $\mathrm{Ha}_{5}$ tidak dapat diterima, hal ini ditunjukan oleh variabel pembiayaan Musyarakah memiliki nilai t $1,139<1,734$ dan nilai signifikansi 0,270>0,05 yang berarti secara parsial variabel pembiayaan Musyarakah tidak

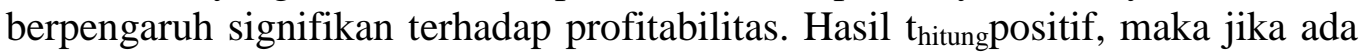
peningkatan dalam jumlah pendapatan margin Musyarakah maka akan meningkatkan pula tingkat profitabilitasnya.

\footnotetext{
${ }^{28}$ Liza Nur Hidayah, "pengaruh pembiayaan Natural Uncertainty Contract (NUC) dan Natural Certainty Contract (NCC) terhadap profitabilitas bank umum syariah periode 2008-2012”.

${ }^{29}$ Nuril Wahidah Rizqi, dkk,

${ }^{30}$ Yesi Oktriani
} 
Dari hasil penelitian yang sudah dilakukan diketahui bahwa dalam setiap periode pelaporan keuangan ditemukan untuk pembiayaan Musyarakah mengalami kenaikan dan juga penurunan. Hal ini disebabkan karena pembiayaan Musyarakah lebih diminati dibanding pembiayaan Mudharabah dan pembiyaaan Istishna' karena dalam pembiayaan Musyarakah termasuk dalam jenis investasi atau penanaman modal antara dua belah pihak atau lebih. Masing-masing pihak saling mengharapkan keuntungan dari hasil usaha yang didirikan. Jadi, pembiayaan Musyarakah ini lebih menjanjikan dibanding dengan pembiayaan yang lain yang memiliki resiko.

Hasil penelitian ini tidak konsisten dengan hasil penelitian Yesi Oktriani (2012) yang menyatakan bahwa pembiayaan Musyarakah secara parsial tidak berpengaruh signifikan terhadap profitabilitas.

Berdasarkan hasil penelitian yang telah dilakukan dapat diketahui bahwa dari variabel pembiayaan Murabahah, Pembiayaan Ijarah, pembiayaan Istishna, pembiayaan Mudharabah dan pembiayaan Musyarakah, variabel yang paling tidak berpengaruh dominan terhadap profitabilitas adalah variabel pembiayaan Mudharabah. Dimana variabel pembiayaan Mudharabah ini tidak mempunyai pengaruh positif dan tidak signifikan. Variabel pembiayaan Murabahah, pembiayaan Ijarah, pembiayaan Istishna, dan pembiayaan Musyarakah mempunyai pengaruh positif tapi tidak signifikan.

\section{Kesimpulan}

Pada pengujian hipotesis dengan menggunakan uji t (secara parsial) dapat dijelaskan bahwa variabel pembiayaan Murabahah memiliki angka signifikansi (P Value) sebesar 0,623>0,05 berarti variabel pembiayaan Murabahah tidak berpengaruh signifikan terhadap profitabilitas (ROA).variabel pembiayaan Ijarahmemiliki angka signifikansi ( $P$ Value) sebesar 0,120>0,05 berarti variabel pembiayaan Ijarah tidak berpengaruh signifikan terhadap profitabilitas (ROA). Variabel pembiayaan Istishnamemiliki angka signifikansi (P Value) sebesar 0,217>0,05 berarti variabel pembiayaan Istishna tidak berpengaruh signifikan terhadap profitabilitas (ROA). Variabel pembiayaan Mudharabahmemiliki angka signifikansi ( $\mathrm{P}$ Value) sebesar 0,232>0,05 berarti variabel pembiayaan Mudharabah tidak berpengaruh signifikan terhadap profitabilitas (ROA). Variabel pembiayaan Musyarakahmemiliki angka signifikansi (P Value) sebesar 0,270>0,05 berarti variabel pembiayaan Musyarakah tidak berpengaruh signifikan terhadap profitabilitas (ROA). 


\section{DAFTAR PUSTAKA}

Ahmad Ifham, Buku Pintar Ekonomi Syariah, 2010

Amalia, Nur dan Fidiana, 2016. Metode Purposive Sampling

Aulia Fuad Rahman Ridho Rohmanika, "pengaruh pembiayaan jual beli, pembiayaan bagi hasil, dan rasio Non Performing Financing terhadap profitabilitas bank umum syariah di indonesia". Jurnal biasa

Ascarya (2007). Musyarakah

Ascarya dan Yumanita (2005:4). Pengertian Bank Syariah, Fungsi Bank Syariah

Bank Indonesia.Pengertian Pembiayaan

Charles Berger dan Richard J Calabrese (1975). Pengertian Uncertainty Reduction Theory

Dessy Mauliza dan Rulfah M.Daud, 2016, "pengaruh kecukupan modal dan kompetisi terhadap profitabilitas bank syariah di Indonesia". Jurnal Ilmiah Mahasiswa Ekonomi Akuntansi (JIMEKA), Vol 1, No 1, Universitas Syaiah Kuala Banda Aceh.

Dewi Istifadah, Arik Susbiyanto, dan Ade Puspito, "Analisis pengaruh giro wadiah, deposito mudharabah dan tabungan mudharabah terhadap profitabilitas perbankan syariah di indonesia". Jurnal biasa

Dita Wulan Sari, 2013, "Pengaruh Pembiayaan Jual Beli, Pembiayaan Bagi Hasil, Financing To Deposit Ratio, dan Non Performing Financing Terhadap Profitabilitas Bank Umum Syariah 2009-2012”. Universitas Diponegoro Semarang

Edhi Satriyo Wibowo, 2012, "Analisis Pengaruh Suku Bunga, Inflasi, CAR, BOPO, NPF Terhadap Profitabilitas Bank Syariah". Universitas Diponegoro Semarang

Eugene F.Brigham dan Joel F.Houston, 2014, Dasar-Dasar Managemen Keuangan (Essensials Of Financial Management), Salemba Empat, Jakarta.

Farida dan Veni Soraya Dewi (2014). Arti dari Sharia Enterprise Theory

Fatwa DSN No. 04/DSN-MUI/IV/2000 tentang Murabahah

Ganang Satriyo Aji, 2016, "Pengaruh Inflasi, BI Rate, CAR, dan NPF Terhadap Profitabilitas Bank Syariah Di Indonesia". Universitas Sebelas Maret

Ghozali (2013). Pengertian Variabel Ortogonal 
Ghozali (2007). Pengertian Uji Normalitas, Uji Multikolinieritas, Uji Heterokedastisitas, uji Autokorelasi

Gita Dwi Cahyani Effendi, 2015, "Pengaruh Total DPK dan Penyaluranya Serta Pergerakan Nilai Tukar Terhadap BOPO pada Bank-Bank Malaysia”. Artikel Ilmiah, Sekolah Tinggi Ilmu Ekonomi Perbanas Surabaya.

Harmono (2009:109). Pengertian Profitabilitas

Iin Nurulita, 2009, "Pengaruh Pendapatan Bagi Hasil Pembiayaan Mudharabah Terhadap Profitabilitas pada PT.Bank Muamalat Indonesia Tbk". Universitas Mercu Buana

Imamul Arifin, membuka cakrawala ekonomi, (jakarta : Setia puma invers 2007, hal 14)

Ismail (2011:138). Perbedaan Harga Beli dengan Harga Jual

Kasmir (2000). Sumber Dana Bank Syariah

Kasmir (2002). Pengertian Pembiayaan

Kasmir (2008). Pengertian Perbankan Syariah

Liza Nur Hidayah, "pengaruh pembiayaan Natural Uncertainty Contract (NUC) dan Natural Certainty Contract (NCC) terhadap profitabilitas bank umum syariah periode $2008-2012$ ".

Lukman Dendawijaya (2009:118). Analisis Rasio Profitabilitas

Mudjarad Kuncoro dan Suharjono (2000). Pengertian Profitabilitas

Muhammad (2002:17). Pengertian Pembiayaan, Tujuan Pembiayaan Syariah

Muhammad Rifqi, 2008, Akuntansi Keuangan Syariah, P3EI-Press, Yogyakarta.

Mustika Rimadhani dan Osni Erza, "Analisis Variabel-variabel yang mempengaruhi pembiayaan Murabahah pada bank syariah mandiri periode 2008". Jurnal biasa

Novi Fadhila, 2015, "Analisis Pembiayaan Mudharabah dan MurabahahTerhadap laba Bank Syariah Mandiri”. Jurnal Riset Akuntansi dan Bisnis, vol 15 no 1, Universitas Muhammadiyah Sumatera Utara.

Nur Amalia, Fidiana, 2016, "Struktur Pembiayaan dan Pengaruhnya terhadap Profitabilitas Bank Muamalat Indonesia dan Bank Syariah Mandiri”. Jurnal Ilmu dan Riset Akuntansi, volume 5, No 5, Mei 2016 , ISSN 2460-0585, Sekolah Tinggi Ilmu Ekonomi Indonesia (STIESIA) Surabaya. 
Nur, Liza Hidayah, 2012. Kriteria Penentuan Sampel

Nur, Liza Hidayah, 2012. Pengertian Hipotesis

Nur Mawaddah, 2015, "faktor-faktor yang mempengaruhi profitabilitas bank syariah". Jurnal etikonomi, P-ISSN : 1412-8969, E-ISSN : 2461-0771, volume 14, No 2, oktober 2015.

Nuril Wahidah Rizqi, Noor Shodiq Askandar, dan Affifudin, "Analisis Pengaruh Pembiayaan Mudharabah, Musyarakah dan Ijarah terhadap profitabilitas bank syariah di indonesia".

Nurulita, Iin.Pengaruh Pendapatan Bagi Hasil Mudharabah Terhadap Profitabilitas. 2009

Pasal 1 ayat 12 UU No. 10 tahun 1998 tentang Perbankan No 105 tentang Jenis Mudharabah

Purwita Sari (2011). Sharia Enterprise Theory

Retno, Dewi Indriaty, 2010. Tujuan Pembiayaan Mikro

Rr.Nadia Arini Haq, 2015, "pengaruh pembiayaan dan efisiensi terhadap profitabilitas bank umum syariah". Perbanas Review, vol 1 no 1.

Russelly Inti Dwi Permata, Fransisca Yaningwati, dan Zahroh Z.A, 2014,"AnalisisPembiayaan Mudharabah dan Musyarakah Terhadap Tingkat Profitabilitas (Return On Equity) (Studi pada Bank Umum yang terdaftar di Bank Indonesia periode 2009-2012)". Jurnal Administrasi Bisnis (JAB), Vol 12, No 1 juli 2014, Universitas Brawijaya Malang.

Santoso dan Tjiptono (2001). Pengertian Populasi

Sudarsi (2002). Rumus ROA

Sugiyono, 2011. Metode Penelitian Kuantitatif, Kualitatif, dan R\&D. Bandung: Alfabeta

Surya Adie Tria Sakti, 2012, "Pengaruh Risiko Pembiayaan, Kecukupan Modal, Efisiensi Operasional, dan Fungsi Intermediasi Terhadap Profitabilitas pada Perbankan Syariah Di Indonesia". Universitas Jember

Triyuwono (2003). Penjelasan Akuntansi Syariah

UU Perbankan Syariah Indonesia No. 21 tahun 2008 jenis bank dan pengertianya 
UU RI No. 10 tahun 1998 tentang perubahan atas UUN No. 7 tahun 1992 tentang Perbankan

Van Horne dan Wachowicz (2009:222). Pengertian Profitabilitas

Vini Trinita, 2015, "Pengaruh Kinerja Keuangan Terhadap Profitabilitas Bank Syariah”. Universitas Muhammadiyah Purwokerto

Wulan, Dita Sari, 2013.Hubungan Profitabilitas Secara Umu

Wulan, Dita Sari, 2013. Pengertian Uji Asumsi Klasik

Yaya, dkk (2009). Pengertian Bank Umum Syariah, Pengertian Bank Konvensional

Yesi oktriani, "Pengaruh pembiayaan Musyarakah, mudharabah,dan murabahah terhadap profitabilitas (studi kasus pada PT. Bank Muamalat, Tbk.)”.

Zaenudin dan Yoshi Erlina, 2012, "Pengaruh Pembiayaan Mudharabah dan Musyarakah Terhadap Pendapatan Bank Syariah”. Al-Iqtishad : Vol V, No. 1, Januari 2013, STIE Ahmad Dahlan Jakarta

Zainul Arifin ( Dasar-dasar Manajemen Syariah )

http://pdfsearchpro.com/bank-syariah-pdf.html.

http://nustaffsite.gunadarma.ac.id/dana-pihak-ketiga-bank-syariah/

https://www.statistikian.com

www.profprojects.com 